\title{
Investigating Botanical Tributes in Post-Medieval British Burials: Archaeological Evidence from Three Burial Grounds
}

\author{
Rachel Ives ${ }^{1}$
}

Accepted: 1 February 2021 / Published online: 8 March 2021

(C) The Author(s) 2021

\begin{abstract}
Archaeological evidence from Britain shows botanical inclusions formed part of the post-medieval funeral. Findings from the analysis of three burial grounds consider the extent of demographic, socioeconomic, and local variation in the manner of tributes. Twenty-six of 1431 excavated burials showed evidence for flowers placed inside or bouquets or wreaths placed on top of the coffins, and adults and children had received botanical tributes. The use of tributes increased during the later nineteenth century but local variation existed in the manner and extent of botanical tributes adopted but trends can be affected by biases introduced by preservation and survival between different sites.
\end{abstract}

Keywords Flowers $\cdot$ Tributes $\cdot$ Britain $\cdot$ Funerals $\cdot$ Commemoration

\section{Introduction}

The material culture of funerary traditions spanning the eighteenth to early twentieth centuries in England has received renewed interest in discussions aimed at promoting, directing, and shaping strategies for cohesive future research in archaeology (e.g., Cherryson et al. 2012; Powers 2015; Renshaw and Powers 2016). This interest can be further situated within a wider context of recent archaeological comparisons made across broader post-medieval landscapes, between the United States, Europe, and Australia, for example, (Mytum 2018; Pitt et al. 2017; Tarlow 2015). Central to this interest lies continuing recognition of the role that archaeological evidence plays in documenting specific aspects of burial practice. Mytum (1989:283), for example, has argued that the direct physical material culture in cemeteries acts to illustrate practices

Rachel Ives

r.ives@nhm.ac.uk

1 Department of Earth Sciences, Natural History Museum, Cromwell Road, London, England SW7 5BD 
that were achieved compared to documentary representations of funerary folklore or tradition. Funerary traditions from this period are most often reconstructed from the archaeological evidence of surviving coffin manufacture and furniture but there is scope for surviving evidence of wider components of the funeral to illustrate details of those traditions that may have limited or incomplete parallels espoused in surviving historical documentation, or to challenge definitions of the norms of such practices (Mahoney-Swales et al. 2011; Renshaw and Powers 2016). One specific aspect of this interest considers the extent to which botanical inclusions formed part of the postmedieval funeral. To date, archaeological evidence for this funerary tradition from the eighteenth century onwards in England is represented by two modes of inclusion: plant remains placed on top of the coffin or lining the grave, and plant/floral remains placed inside the coffin (e.g., Cherryson et al. 2012). However, little is known of the consistency in the manner of tributes, or patterns in who received such commemorations. A comparative synthesis is required to develop interpretations beyond the descriptive presence or absence of this evidence and can broaden current understanding of funerary practices utilizing botanical remains from the eighteenth century. Burial archaeology can provide important insights into the manner of commemorations made by loved ones during the funeral, but personal expressions of grief can be mediated by social and cultural traditions as was particularly evident during the post-medieval period where personal grief was bound together with the need for outward perceptions of social standing. This was strongly manifest in concerns for the provision of what was determined to be a "decent" funeral; one devoid of associations with pauperism or dependency on parish aid (Houlbrooke 1998; Laqueur 1983; Walvin 1982), and social tendencies often that meant funeral displays were mimicked across differing socioeconomic classes (Litten 1991; Stevens Curl 2000:195). While ascribing meaning to funerary customs can be especially complex (Cox 1998:116), exploring the extent to which variation existed in the manner and frequency of botanical commemorations, and consideration of possible factors influencing any such variation, such as demography, family groupings, date of death, or estimated socioeconomic status, provides an important means of developing better insights into the adoption of these tributes in the funeral. This paper presents a comparative study of botanical inclusions found during three archaeological investigations in burial grounds operating between the eighteenth and early twentieth centuries to examine social and cultural funerary practices and develop understanding of the post-medieval funeral.

\section{Materials}

Three archaeological investigations are compared here to assess the evidence for the use of botanical remains in the funeral tradition. Archaeological works at each site were a requirement on the removal of burials as a condition on planning permission ahead of construction, although the nature of the archaeological involvement at each site varied. Each set of works was carried out under appropriate Church of England Faculty permission or burial licence issued by the UK Ministry of Justice.

At the first site, a watching brief was carried out on the exhumation of 200 burials dating between 1840 and 1933 from two areas at St. Mark's Church, Surbiton, Royal London Borough of Kingston (MKU09). Surbiton developed from a rural settlement 
into a fashionable commuter suburb from 1845 and St Mark's Church was constructed in 1844 to accommodate the requirements for additional burial space in the suburb (Jarvis 1960; Walford 1894). The construction of the graves had been standardized and comprised brick-built single or double-width structures designed to hold vertically stacked burials, representing careful and deliberate planning of the burial space, expenditure on grave construction, and, by inference, the likely use of burial costs towards off-setting high grave construction costs. The grave construction prevented truncation and the coffins were well-preserved with some found with elaborate metal decorations and fixings (Ives 2013). Of the 200 burials exhumed, 196 were inhumation burials comprising 101 lead coffins and 92 wooden coffins and represented $164(\mathrm{n}=$ $164 / 196,83.7 \%)$ adults and $29(\mathrm{n}=29 / 196,14.8 \%)$ children. The remaining seven burials were cremation burials (Ives 2013) and these have been excluded from this analysis. The 92 wooden coffins were visually assessed for the presence of botanical remains inside the coffin and grave fill, and these together with the 101 intact lead coffins were recorded for the presence of botanical tributes placed on the coffin lid (Table 1).

At the second site, archaeological works were conducted in the churchyard of St John the Baptist Church in Egham, Surrey (SJE15), and comprised the excavation of pre-1900 burials to a $2 \mathrm{~m}$ deep foundation level and watching brief on burials found post-dating 1900. Two hundred and four graves were archaeologically recorded (Capon and Ives 2015). The burials from St. John the Baptist Church, Egham, also represent a suburban population and the rural village experienced population expansion during the eighteenth century. The existing church of St. John the Baptist was built between 1817 and 1820 but surviving coffin plates dated burials between 1781 and 1897 and the stratigraphic sequence of burial extended before and after these dates (Capon and Ives 2015). The graves were predominantly earth-cut with only 18 brick-built structures comprising both single-width brick-built graves and large brick-built vaults found. The graves were vertically stacked but many were heavily truncated; only $28.9 \%(n=59 /$ 204 graves) were single burials and not impacted on by other graves. At both sites there was a marked bias in the number of adult burials found in the churchyard under archaeological investigation compared to the number of child burials; at St. John the Baptist Church, Egham, only 20 of the 204 burials excavated were children.

Three vaults underneath St John the Baptist Church, Egham, held 30 coffins that were archaeologically recorded ahead of planned space alterations, but many had been moved between the vaults in recent history disturbing the preservation of some of the outer wooden coffins and causing displacement of coffin furniture. As a result, the

Table 1 Summary of the number and type of botanical remains found relative to the number of burials recorded across the three sites

\begin{tabular}{llll}
\hline Site & $\begin{array}{l}\text { Wreaths } \\
\text { on coffin lids }\end{array}$ & $\begin{array}{l}\text { Bouquets } \\
\text { on coffin lids }\end{array}$ & $\begin{array}{l}\text { Flowers } \\
\text { inside coffin }\end{array}$ \\
\hline St Mark's Church, Surbiton & $20 / 193$ & $2 / 193$ & $0 / 92$ \\
St John the Baptist Church, Egham & $1 / 74$ & $1 / 74$ & $0 / 149$ \\
St John's, Peel Grove, Bethnal Green & $0 / 1029$ & $0 / 1029$ & $2 / 1030$ \\
Total & $\mathbf{2 1 / 1 2 9 6}$ & $\mathbf{3 / 1 2 9 6}$ & $\mathbf{2 / 1 2 7 1}$ \\
\hline
\end{tabular}


burials in the vaults were excluded from this study. A total of 149 burials were visually assessed for botanical remains placed inside the coffin or grave, and 74 coffins were sufficiently intact to be recorded for evidence of botanical remains having been placed on the coffin lid and among the latter were 21 were lead coffins (see Table 1).

At the third site, an archaeological excavation was carried out in a former privatelyrun and unconsecrated burial ground at St. John's School, Peel Grove, Bethnal Green, London (PGV10) (Ives 2015). The ground was in use between 1840 and 1855, and 1033 of the original 20,000 burials were excavated from vertically stacked graveshafts and comprised 305 adults and 728 juveniles. By mid-nineteenth century, Bethnal Green had become one of London's most impoverished parishes and sanitary reformers noted concerns over high levels of illness and mortality (e.g., Gavin 1848). At the site, most burials were made in single-shelled wooden coffins; two juveniles were found in complete double wooden coffins and a further two child burials were found without any coffin traces or staining and are likely to have been shrouded. Three lead coffins were discovered during the excavation, including one coffin of a juvenile burial found in an outer wooden coffin buried in the main cemetery. The remaining two lead coffins were adult burials found in a deep waterlogged vault that could not be fully excavated and as it was not possible to assess any survival of botanical remains from the two adult burials, these have been excluded from study. A total of 1029 coffined burials from this site was assessed for botanical remains surviving on coffin lids and 1030 coffins were assessed for plant remains inside the coffins (see Table 1). At each site, on-site recording of the coffins was carried out and included documentation of construction, preservation, size and decoration together with any visible evidence of surviving metal wreath frames, botanical remains on the coffin lid and any visible evidence of botanical remains in the coffin/grave fill.

\section{Results}

Twenty-six burials were found with botanical tributes, which when compared to a crude rate of the total burials at each site creates a frequency of $1.81 \%$ of burials found with such tributes $(n=26 / 1431$ excavated burials). Three modes of plant-based tributes were found comprising floral remains placed directly inside the coffin, wreaths placed on the coffin lid, and bouquets placed on the coffin lid. Burials from all three sites showed at least one type of botanical inclusion. A more meaningful frequency of the number of burials found with each type of tribute relative to the number of burials assessed is shown in Table 1, and each burial with botanical remains is summarized in Table 2 .

\section{Floral remains inside coffins}

Floral remains were found placed directly inside two coffins; both were found at St. John's School, Bethnal Green $(n=2 / 1494,0.1 \%)$ and were child burials. Fragile waterlogged remains of multiple yellow flowers were found in coffin (PGV1865) of a child aged by skeletal development as between one and six months of age at death. These appeared to be inflorescences of Sweet William (Dianthus barbatus L.) (Robertson 2012) although the remains disintegrated when lifting from the coffin 
Table 2 Summary of the archaeological evidence for botanical remains identified among burials from St. Mark's Church (MKU), Surbiton, St. John's Church (SJE), Egham, and the St. John's School (PGV), Peel Grove, Bethnal Green. Biographical details on individual age and sex are shown for MKU and SJE as recorded from surviving coffin plates, $\mathrm{M}$ male, $\mathrm{F}$ female and individual age is given as adult and sex is given as $\mathrm{n} / \mathrm{a}$ where damage to coffin plate obscured this detail or no coffin plate survived

\begin{tabular}{|c|c|c|c|c|}
\hline $\begin{array}{l}\text { Site and } \\
\text { burial } \\
\text { number }\end{array}$ & $\begin{array}{l}\text { Age } \\
\text { (years) }\end{array}$ & Sex & $\begin{array}{l}\text { Year of } \\
\text { death }\end{array}$ & Description \\
\hline MKU1041 & Adult & $\mathrm{F}$ & 1890 & Wire cross on coffin plate on chest \\
\hline MKU1052 & Adult & $\mathrm{F}$ & 1904 & Circular wire wreath on foot of coffin \\
\hline MKU1068 & 5 & M & 1880 & Two circular wire wreaths on chest of coffin \\
\hline MKU1070 & Adult & M & 1881 & Five circular wire wreaths on head, chest and foot of coffin \\
\hline MKU1127 & 69 & $\mathrm{~F}$ & 1879 & Two circular wire wreaths on head and foot of coffin \\
\hline MKU1134 & 45 & $\mathrm{~F}$ & 1884 & Five circular wreaths; three on head and two on foot of coffin \\
\hline MKU1232 & 79 & M & 1891 & Three circular wire wreaths; one on head, two on feet of coffin \\
\hline MKU1247 & 12 & M & 1873 & Circular wire wreath on head of coffin \\
\hline MKU1250 & 52 & M & 1883 & $\begin{array}{l}\text { Three circular wire wreaths; one on head, one on chest, one on foot } \\
\text { of coffin }\end{array}$ \\
\hline MKU1267 & 40 & M & 1885 & One circular wire wreath on head, one wire cross on chest of coffin \\
\hline MKU1330 & 54 & M & 1897 & Two circular wire wreaths; one on head, one on foot of coffin \\
\hline MKU1367 & 89 & M & 1894 & Wire wreath in the shape of an anchor on chest of coffin \\
\hline MKU1393 & 38 & M & 1894 & One circular wire wreath on head, one wire cross on chest of coffin \\
\hline MKU1449 & 86 & $\mathrm{~F}$ & 1891 & One circular wreath on chest of coffin \\
\hline MKU1458 & 30 & M & 1890 & Coffin lid covered with wire mesh \\
\hline MKU2036 & Adult & M & 1883 & Two circular wire wreaths, one on head, one on foot of coffin \\
\hline MKU2120 & Adult & $\mathrm{F}$ & 1894 & Two circular wire wreaths, one on head, one on foot of coffin \\
\hline MKU2137 & 6 & M & 1880 & Circular wire wreath on chest of coffin \\
\hline MKU2143 & 2.7 & M & 1882 & Two circular wire wreaths, one on head, one on chest of coffin \\
\hline MKU2146 & Juvenile & $\mathrm{F}$ & 1879 & Two circular wire wreaths, one on head, one on foot of coffin \\
\hline MKU1121 & 70 & M & 1888 & Traces of leaves of plant remains on coffin plate \\
\hline MKU1062 & 37 & M & 1913 & Traces of plant stems tied with ribbon on coffin plate \\
\hline SJE107 & 35 & M & 1878 & $\begin{array}{l}\text { Traces of a cross made of plant material, possibly hay, placed on the } \\
\text { coffin plate }\end{array}$ \\
\hline SJE68 & 81 & $\mathrm{~F}$ & 1897 & $\begin{array}{l}\text { Remains of the stem of a bouquet tied with a plant stem and placed } \\
\text { on the coffin plate }\end{array}$ \\
\hline PGV1651 & $1-6$ & & & months \\
\hline $\mathrm{n} / \mathrm{a}$ & $1840-55$ & & & Water-logged remains of yellow flowers inside coffin \\
\hline PGV1865 & $1-6$ & & & months \\
\hline $\mathrm{n} / \mathrm{a}$ & $1840-55$ & & & $\begin{array}{l}\text { Desiccated remains of flower heads held in child's hands adjacent } \\
\text { to pelvis inside coffin }\end{array}$ \\
\hline
\end{tabular}

preventing more precise identification (Fig 1a). In contrast, desiccated floral remains were found in coffin (PGV1651) of a child aged between one and six months. These floral remains were found among the bones of the hands which lay over the pelvis. While the desiccated nature of the plant remains made identification difficult, 
comparisons with modern reference material indicated these were most likely examples from the Asteraceae family, which includes asters, daisies, marigolds, chrysanthemums, dahlias, zinnias, and heleniums (Robertson 2012) (Fig 1b).

\section{Wreath remains}

In total, 21 coffins of 1298 found with preserved coffin lids (1.6\%) had surviving evidence of wreaths and variations of this type of botanical tribute were found at two of the three sites. Twenty burials from St Mark's Church were found with various shapes of wire frames representing wreaths which were placed on top the coffin (see Table 2). These 20 burials were embellished with a total of 41 wreath frames, most often represented by the traditional circular wreath shape, but other instances of different shapes were found including wire crosses and rectangular frames and in one instance a wire formed in the shape of an anchor (see Table 2, Fig. 2). Of the 20 burials with wire wreath frames, only seven individuals were found with a single frame of any shape. Notably the number of circular wreath frames used varied and ranged from four individuals buried with one wreath to two individuals buried with five wreath frames each and circular wreaths frames were also used together with frames of other shapes, such as crosses in two instances (see Table 2). In one instance, a metal wreath was formed with stylized leaves forming the circle. The wire wreath frames clearly contrasted lid motifs that can have a similar appearance such as the motif of a serpent eating its tail symbolizing eternity and everlasting life (Stevens Curl 2000:203).

The individuals found with wire wreath frames from St. Mark's Church comprised 15 adults and five children and where individuals could be identified by surviving coffin plates it was clear that those with wire wreaths frames were not members of the same family. There was also no clear consistency in the use of a particular type of wreath design, or number of wreaths, associated with an individual by their age or sex as determined from surviving coffin plates (see Table 2).

No wire wreath frames were found associated with burials from St. John the Baptist Church, Egham, or from St. John's, Peel Grove, Bethnal Green. As such, the frequency of individuals found with wire wreath frames among the excavated burials in this study
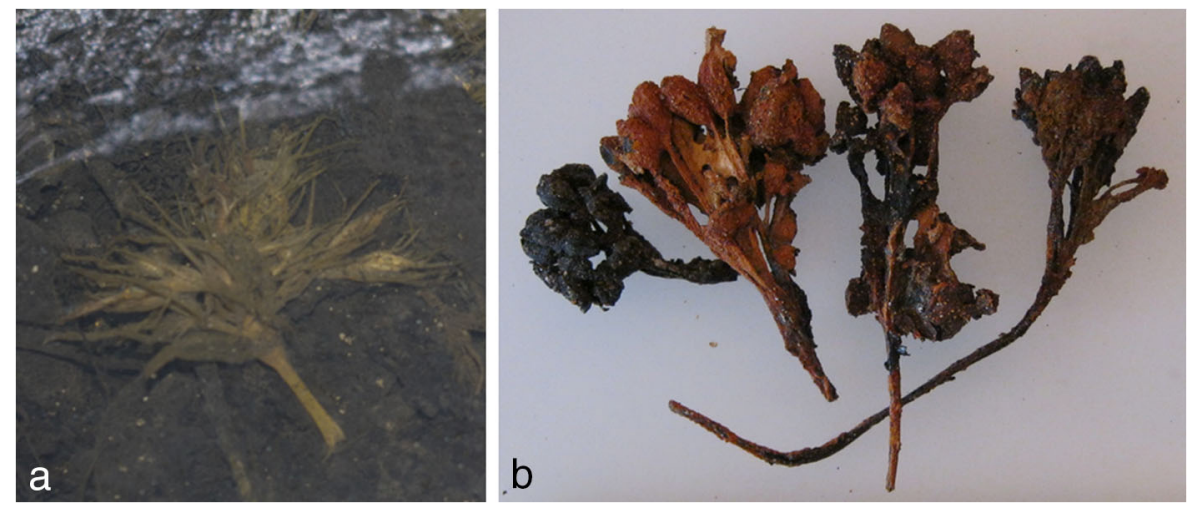

Fig. 1 a Yellow inflorescences thought to be Sweet William present in a water-logged coffin of a 1-6-monthold child from St. John's School, Bethnal Green, London. b Desiccated remains of flowers, possibly daisies or asters, found in the hands of a 1-6-month-old child from Bethnal Green, London 


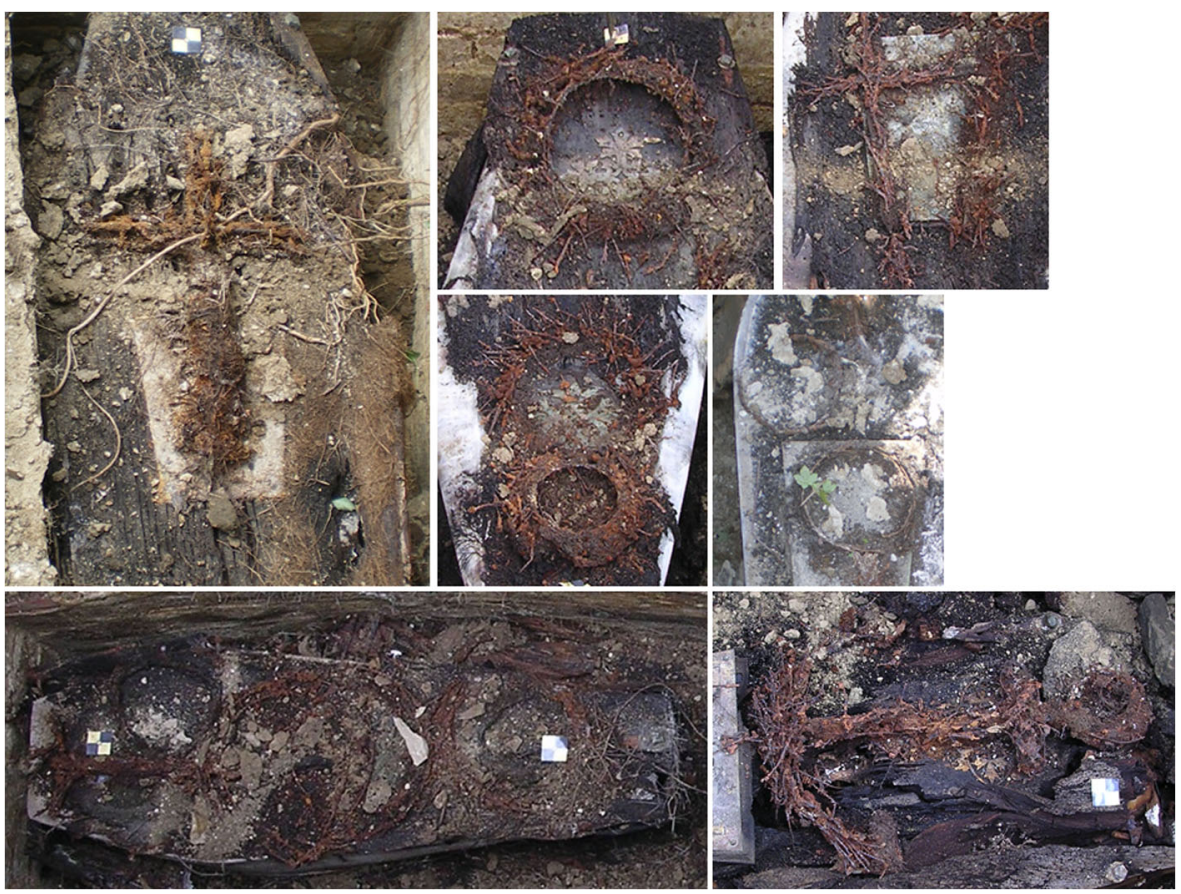

Fig. 2 Composite image showing the variation of wire wreath frames found at St. Mark's Church, Surbiton. Wire frames in the form of crosses and multiple circular wreaths and an anchor placed on coffins are shown. Note green foliage in central image is modern and not related to the wreath frame

is $1.3 \%$ (20/1494). Despite the lack of evidence of wire wreath frames, one burial from St. John the Baptist Church, Egham, was found with plant material deliberately formed into the shape of a cross (Fig. 3). This cross was placed on the coffin plate of an adult male (SJE107) aged 35 years of age, who died in 1878. The cross was made from plant stems and measured $39 \mathrm{~mm}$ in length. There was no evidence of leaves, flower stems or heads among the plant stems, although it is probable that not all original inclusions had survived. It is likely that this was intended to form an organic version of a wire frame of wreath cross such as those found at St. Mark's Church, Surbiton. The adult male with a wreath cross from Egham was buried in a brick-lined grave and the lack of surrounding earth fill is likely to have influenced the survival of the plant remains.

\section{Bouquets}

Tied bundles of plant stems forming bouquets were found placed on coffin plates of three adult burials of 1298 recorded coffins with surviving lids $(0.2 \%)$ and examples of bouquets were found at two of the three sites. Gathered plant stems held together with surviving traces of ribbon tied around the bundle were found placed on the coffin plate of an adult male who died in 1913 aged 37 years and was buried at St. Mark's Church, Surbiton, (MKU1062) (Fig. 4a). No flower heads had survived in this bouquet. Traces of leaves found over the coffin plate of a second burial from St. Mark's Church, Surbiton, were thought to have formed a gathered bunch commemorating adult male (MKU1121) who was 70 years old at his death in 1888. A third example of a bouquet 


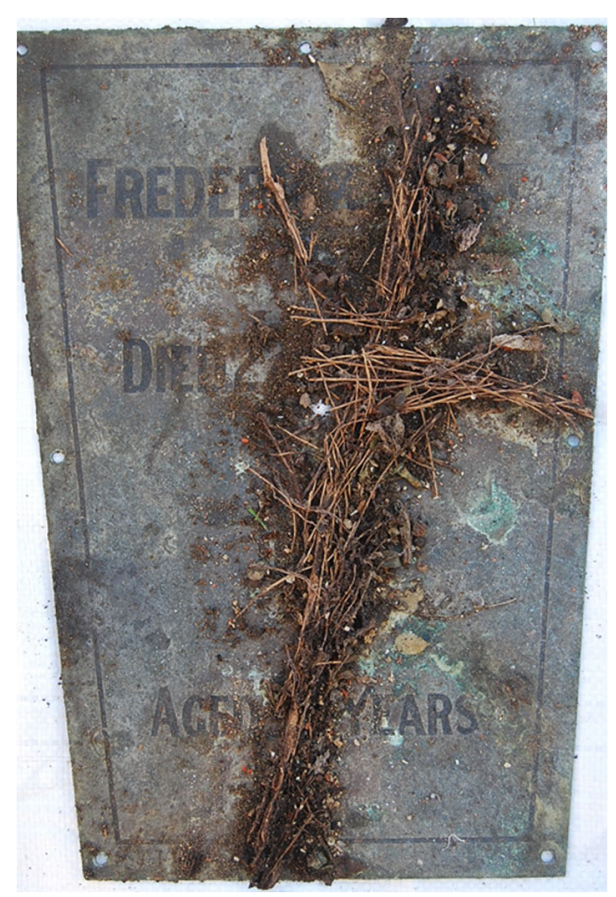

Fig. 3 A wreath in the form of a cross formed of surviving plant material, possibly hay and placed over a coffin plate found at St. John the Evangelist Church, Egham

was found placed on the coffin plate of an adult female (SJE68) who died aged 81 years in 1897 and was buried at St. John the Baptist Church, Egham. This bouquet had been damaged since the time of deposition, but several stems and leaves had survived (Fig. 4b) and most notably, a plant stem had been used to gather the stems and had been tied a knot around the bundle (Fig. 4c). All individuals found with surviving bouquets were buried in brick-lined graves and, as outlined above, survival of these botanical tributes was likely influenced by the protection from direct contact with soil.

\section{Demography of burials with botanical remains}

Of the 26 burials found with evidence of botanical tributes, $19(73.1 \%)$ were adults (18+ years) and the remaining seven burials $(26.9 \%)$ were children less than 18 years of age (see Table 2). The two burials with flowers placed inside the coffin were both child burials and this form of commemoration was used in the funerary rite of children from a young age as flowers were placed in the coffins of two children who were each less than six months old when they died and were buried at Bethnal Green. Neither coffin had a surviving coffin plate, therefore the sex and more specific age-at-death of these individuals is not known.

The remaining 24 individuals found with wire wreath frames or bouquets placed on top of the coffin comprised burials with surviving coffin plates and burials without. As it was not possible to identify all burials, demographic patterns of those found with botanical tributes are considered with some degree of caution. Seventeen of the 24 burials with wreath frames or bouquets were identified from complete coffin plates and 


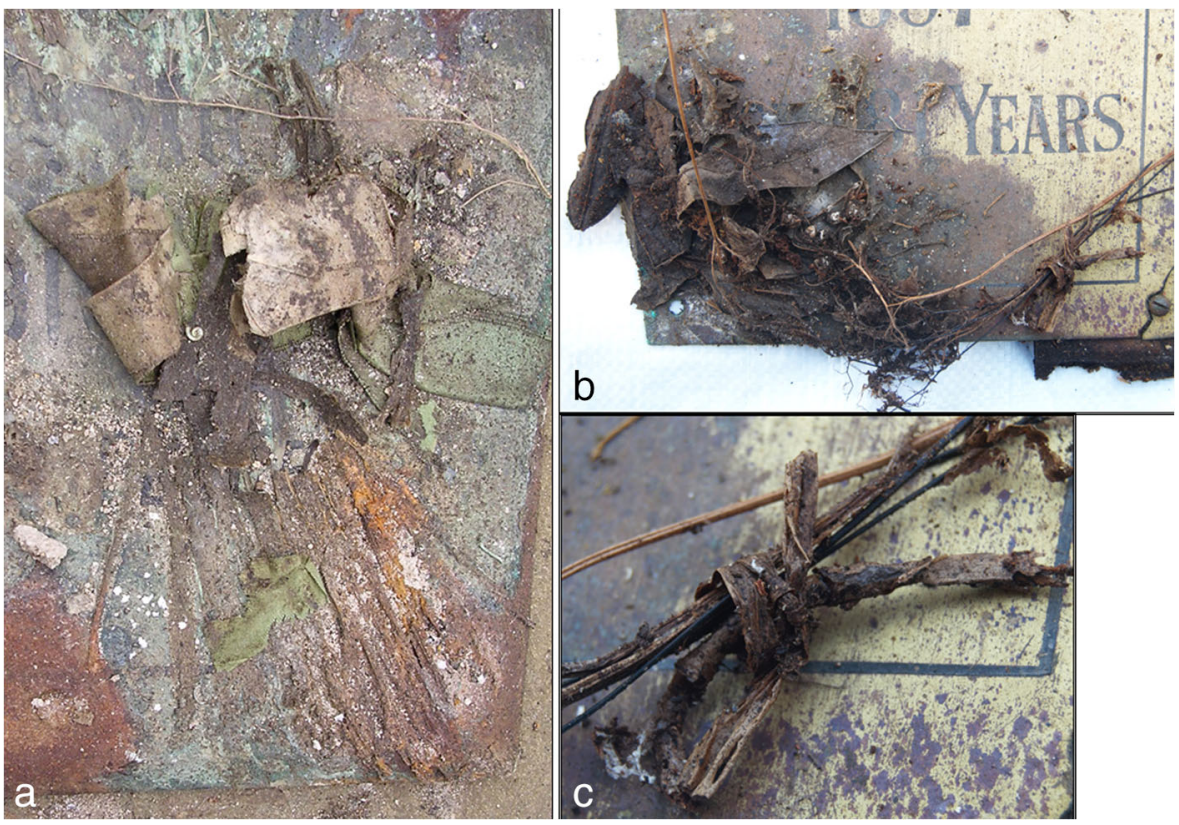

Fig. 4 Examples of the bouquets remains from two sites. a Detailed view of a tied bunch of plant stems with remnants of ribbon found placed over a coffin plate from St. Mark's Church, Surbiton. b Overview of remains of a bouquet with surviving plant stems and leaves bunched together and held in place by a plant stem tied in a knot placed on a coffin plate at St. John the Evangelist Church, Egham. c Detailed view of the plant stems knotted and tied around the remaining stems of the bouquet from (b)

were represented by 13 adults and four children. The remaining individuals without complete coffin plates were estimated as a child or adult based on partial inscriptions of ages or surviving titles (e.g., Master, Mrs., Mr.) and broad estimates of coffin size; the remaining individuals with botanical remains and ages estimated in this fashion included six adults and one child (see Table 2).

Interestingly, wire wreath frames were placed on coffins of children from a relatively young age; the youngest individual commemorated in this manner was two years and eight months old. Wreaths were also used for children aged five and six years old, and the oldest child found with a wire wreath frame was 12 years old. While wire wreath frames were more frequently found with adult burials, it is significant that child burials were commemorated in a similar fashion. Among the identified adult sample found with botanical tributes, the youngest individual was 37 years of age while the oldest identified individual was 89 years old. There was a relatively even distribution of individuals found with botanical tributes across the adult age range (see Table 2) and no evidence for a trend of greater usage of this form of funerary commemoration for any particular age range (e.g. young adulthood or older age).

Except for the two unidentified children found with flowers inside the coffins at Bethnal Green, all the remaining 19 adults and five children with botanical tributes had an identified sex determined from the surviving coffin plate. Botanical tributes were found with both adult males and females although there was a male bias with 12 adult males (63.2\%) with botanical tributes compared to seven adult females (36.8\%). A male bias was found among children as four male children had wire wreath frames 
compared to one female child. In total, 16 males (adults and children combined) were found with evidence of wire wreath frames/bouquet remains compared to eight females (adults and children combined). The proportion of males and females across each burial ground is not known and osteological analyses were limited in places by the presence of lead coffins. Accordingly, the trend for an apparent male bias in burials found with wire wreath frames/bouquets also needs to be interpreted with care. Notwithstanding this cautious approach to interpreting the demography of those with botanical tributes, the results are significant in demonstrating that both adults and children were commemorated with various forms of botanical tributes during the dates of use of these three burial grounds, and adults and children were commemorated by the same tribute form of wreaths. Differences in the tributes were found whereby flowers were found placed inside the coffins of two children and bouquets were found placed on top of the coffins of adult burials. Males and females were commemorated with botanical remains as part of their funerary rite, although an apparent male bias is indicated in the sample, but it is not known whether this could be influenced by the overall sample composition.

\section{Dates of botanical commemorations}

It was of interest to determine whether evidence existed for specific phases of use of botanical tributes in the sample although any patterns can be biased by taphonomic differences affecting the survival of evidence between sites. The two child burials found with flowers inside their coffins from Bethnal Green demonstrate that this practice was in use during the mid-nineteenth century as the burial ground was only in use for 15 years covering 1840 to 1855 and these results add to the growing evidence for this funerary rite from this time (see Discussion). However, the dates of death for these two individuals could not be identified more specifically as the stratigraphic sequence at this site showed that some burials were moved between graveshafts, potentially during phases of grave reworking and expansion (Ives and Hogg 2012; see also Renshaw and Powers 2016 for similar discussion of postmedieval site stratigraphy). As a result, it is not possible to assume a straightforward stratigraphic sequence of interment existed to allow tighter dating of these two child burials.

Those burials that could be securely dated by surviving coffin plates show that botanical remains were included in funerals at St. Mark's Church, Surbiton, and St. John the Baptist Church, Egham, between 1873 and 1913 (see Table 2). In particular, surviving evidence shows that wreaths were used to commemorate individuals who died between 1873 and 1904 although there was no clear pattern in the presence of wreaths for male or female burials at different periods across this date range (see Table 2). The dates of the five child burials found with wire wreath frames from St. Mark's Church, Surbiton, cluster towards the early range of dates of the whole sample and specifically range between 1873 and 1882. However, as only 29 of the 196 burials recorded during the archaeological works at this site were children, it is not possible to know whether this pattern reflects a genuine trend for more limited use of wreaths for child burials to within the early 1880 s, or whether this pattern is simply reflective of the overall small number of child burials. While a small number of individuals were found with evidence of bouquets placed on the coffin lid, the use of these tributes dated between 1888 and 1913. 


\section{Discussion}

The archaeological evidence reported here demonstrates that a range of botanical tributes formed part of the funerary tradition during the post-medieval period. The botanical remains represent three different forms of plant-based funerary tribute and expand on current knowledge of the deliberate inclusion of plant remains placed on top of and within coffins between the nineteenth and early twentieth centuries. This discussion reviews the period of use covering these forms of tributes and presents insights into the patterns of use of this funerary tradition from historical and archaeological evidence to contextualise the significance of these results.

\section{Botanical remains inside coffins}

Surveys have highlighted historical descriptions of plants being deliberately placed into the coffin as part of the funerary tradition (e.g., Cherryson et al. 2012). Drury (1994:102), for example, discusses thyme (Thymus vulgare) being dropped into the coffin and sprigs of common or European Yew (Taxus baccata) placed directly into shrouds with likely connotations of resurrection and eternal life. Cox (1998) and Gittings (1988) both refer to historical examples where flowers and herbs were placed within winding sheets and wrapped around the body, thought to help freshen the corpse together with the use of scents such as rosewater. Walvin (1982:370) also stated flowers could provide an "aromatic antidote against the unmistakable smell of death" and Litten (1991:92) referred to rosemary occasionally added to bran or sawdust in the bottom of a coffin to counteract the smell of decomposition. Stone (1858:274) attributed rosemary's popularity in use as to its greenness and fragrance, and it was also symbolically associated with remembrance (Cox 1998:116). Drury (1994) similarly referred to the use of strong-smelling herbs in the house where the deceased was held until the day of the funeral although Cox (1998) has argued these methods may not have been wholly effective.

Archaeological evidence also attests to botanical remains being deliberately placed inside coffins during the post-medieval funeral and box hedge (Buxus sempervirens), thought to represent life everlasting (Cox 1998:116), has been frequently recovered; examples were found in three coffins from St. Martin's-in-the-Bull Ring, Birmingham, and in two of these, flower buds were present on the box sprigs indicating a spring date of burial (Ciaraldi 2006). Box hedge was also found in one burial from City Bunhill ground (Connell and Miles 2010:10) and box leaves, sprigs and possible yew and bay (Laurus noblis) were found in the coffin of an adult female burial from the St. Pancras burial ground, London, and box together with bay leaves were found in a second coffin of an adult female from this site (Giorgi 2011), the bay laurel likely linked to the symbolism of resurrection (Stone 1858:273). Giorgi (2011:188) has also described a nineteenth century burial from West Kensington, London in which box and holly (Ilex aquifolium) were found and Cherryson et al. (2012:79) reported box leaves with surviving traces of gilded paint, which possibly formed an arrangement placed over the chest of an individual from St. Peter's Church, Carmarthen.

While box and bay appear popular inclusions at this time, two further burials from St. Martin's-in-the-Bull Ring, Birmingham were found with juniper twigs (Juniperus communis L.) and cherry leaves (Prunus avium/cerasus). Ciaraldi (2006) and Boyle 
and Keevill (1998) reported several wooden coffins buried at St. Nicholas Church, Sevenoaks, Kent, containing traces of flower petals surviving above and below the human remains dating from the eighteenth and nineteenth centuries, while a bunch of lavender (Lavandula sp.) and rosemary (Rosmarinus officinalis) was found in the coffin of a 79-year-old male who died in 1845 (Boyle and Keevill 1998). Woody vegetation had survived in the coffin of an adult male from 1748 in Dalton described by Cherryson et al. (2012) and Cox (1998:116) noted plant remains were also found on or in coffins from St Barnabas Church, West Kensington, London.

Historical evidence referring to the placement of flowers rather than evergreen foliage and herbs inside post-medieval coffins appears more limited. Jalland (1996:214) mentions a poignant example of flowers from a wedding bouquet being placed within in a coffin and Drury (1994:102) draws on folklore references to wallflowers, roses and other sweet-smelling blooms placed in the coffins of the poor, and noted common rue (Ruta graveolens), hyssop (Hyssopus officinalis) or wormwood (Artemisia absinthium) were placed inside coffins. Cunnington and Lucas (1972:142) state Victorian convention was for funeral flowers to be white or purple, not black, although whether flowers were to be placed inside the coffin or on top of the coffin is not clear. These authors described an instance where flowers were scattered over the body of an infant child of an officer and his wife in India in 1854 (Cunnington and Lucas 1972:270). An article in the Illustrated London News from 1864 stated that the "the lily, the rose, the azalea all white save a few violets" were "all appropriate to scatter over the dead" (cited in Cunnington and Lucas 1972:142) and most likely indicating decorating the body in the coffin. Gittings (1988:73) reported an instance of burial at a crossroads of a girl who committed suicide whereby flowers were thrown onto her body, and Fletcher mentions an example of cowslips being laid on the chest of an 18 year old by her parents at her burial in 1829 (Fletcher 2010:86 citing Russell 1853:22).

Similarly, there is limited archaeological evidence of floral remains found within post-medieval coffins. One burial found from St. Martin's-in-the-Bull Ring, Birmingham was found with wild/garden privet (Ligustrum vulgare/ovalifolium), but it was unclear whether this had formed a foliage wreath as Ciaraldi (2006) questioned whether the honey-scented flowers had been selected and placed with the individual inside the coffin. Archaeological evidence for a wire frame for a wreath or garland was found inside the coffin of a 18-25-year-old female burial from New Bunhill Fields, Southwark, London, broadly dating between ca.1821 and 1853 (Davis and Miles 2012:58) and at the same site a striking example of the coffin of a four-month-old male child was found full of yellow wallflowers (Erysimum cheiri) covering the head and shoulders of the child's body (Davis and Miles 2012:56). Wallflowers were popular in the Victorian period (Drury 1994) and were highly scented in April and May, which Davis and Miles (2012:56) suggest is likely to have influenced their use in the funeral of this child which took place in April, 1842. In addition, a five-month-old infant from New Bunhill Fields was found with stems, leaves, and unopened flower buds, possibly of the Rosaceae family (e.g., apple Malus sp., pear Pyrus sp., or whitebeam Sorbus sp.), inside the coffin (Davis and Miles 2012:56). The deliberate inclusion of floral remains thought to represent Sweet William (Dianthus barbatus L.) and the Asteraceae family (asters and daisies, marigolds, chrysanthemums, dahlias, zinnias, and heleniums) in the coffins of two child burials from St. John's, Bethnal Green, are significant in adding to the 
number of individuals found to date with evidence of this direct form of botanical commemoration. Importantly, these examples also expand on the known range of floral remains used to commemorate child burials at this time in London.

Goody (1993:184) notes that from the Tudor period there was a growing trend for flowers and herbs to be brought into the home and kept in pots, especially those that were sweet smelling. The deliberate cultivation of flowers was predominantly an indulgence of the rich although interest in gardening expanded such that some in the middle classes developed flower gardens (Goody 1993:183). Fluctuations in market prices and supplies prompted a rise in professional gardeners and the import of flowers (Goody 1993:184) but growing cultivation in hot-houses or conservatories helped flowers to become increasingly used in the home (Goody 1993:185). Cultivated flowers were used in outward displays of celebration; Stone (1858:275), for example, refers to an Easter wreath made of hyacinths, camellias, azaleas, narcissus, lily, and roses chosen to represent "beautiful flowers of the conservatory" mixed with evergreens that were "emblems and tokens of a resurrection from the grave, a new life hereafter." Wildflowers were also utilized in a variety of ways including in funeral traditions. Goody (1993:267, 292) discusses examples of wildflowers given as gifts and as "the playthings of children," and Seaton (1995:11) highlights poetry referring to flowers given as gifts to a poor child to lay on the coffin or "place in the dead hand of a baby sister." While Beaton notes this was often used as a cliched literary example, it is paralleled in the young child found holding flowers at St. John's, Bethnal Green. The inclusion of wildflowers such as daisies in the coffins of the child burials from Bethnal Green were most likely personal tributes likely from parents or siblings and it is possible that flowers were cut from plants that grew close to the homes of each child or nearby in the parish. While living and environmental conditions in the parish were reportedly dire by mid-nineteenth century, a survey of the sanitary condition of the parish carried out by Hector Gavin described an area of land in "Whisker's Gardens" which were originally laid out as garden plots with summer houses but were being built over for permanent lodgings at the time of his survey in 1848. Gavin (1848:1112) observed that "The weary artisan and the toil-worn weaver here dedicate in their spare hours... the cultivation of beautiful flowers." If available, garden flowers would have been extremely economical to include as tokens at the funeral.

Archaeological evidence found to date illustrates that the inclusion of botanical remains directly inside post-medieval coffins was a tradition used for burials of both adults and children. A trend for evergreens and leafy plants and herbs to be placed with adults may be broadly more fitting with symbolic representations of eternal life and resurrection but these remains are likely to survive better than floral remains, potentially biasing interpretations of the type and frequency of botanical commemorations at this time. It is interesting that examples of floral remains as opposed to evergreens or herbs have been found with child burials from London to date, although the small number of individuals found with floral remains limits interpretations to some extent and it is not possible to determine if this is a chance occurrence in the samples excavated so far. The survival of the floral remains at St. John's, Bethnal Green, was aided by a high water table and natural clay allowing the coffin wood and botanical remains to survive. As these factors will vary considerably between sites the likely survival of botanical remains will also vary. Interpretations are also limited by the avoidance of opening sealed lead coffins due to health and safety concerns, which may bias the results from 
both time periods and socioeconomic groups that show a greater tendency for the use of lead coffins. However, as more sites under development are studied, it may be possible to identify whether differences exist in the choice of botanical remains used depending on status, age, or sex. The evidence of the inclusion of this botanical tribute placed directly within the coffin reflects a personal or private form of commemoration observed by those in the presence of the deceased prior to the closure of the coffin and burial. As such, this tribute was not intended to form a visible component of the funeral; once the coffin lid was sealed there would have been no outward evidence of the involvement of botanical remains in the funerary practice.

\section{Flowers placed on the coffin}

Various historical sources have highlighted that plants were often included in the funeral by being thrown onto the coffin. Drury (1994:102), for example, reported instances in which evergreens including rosemary, ivy, and laurel, often representing the immortality of the soul, were carried during the funeral and thrown onto the coffin in the grave and an example of this is reported on by Litten (1991:144). Drury (1994:102) also noted examples where rosemary sprigs as well as sprigs of box were gathered in pots in the house where mourners would assemble, allowing gatherers to take sprigs to the funeral. Puckle (1926) referred to mourners dropping springs of box and rosemary onto the coffin before leaving the graveside (see also Cunnington and Lucas 1972:137) and Drury (1994:102) found various references to bay laurel being thrown onto seventeenth-century coffins symbolizing hopes of resurrection (see also Cox 1998:116), and noted references to the scattering of rosemary, hyacinths, cypress, and yew at the entrance to a London charnel house. Drury (1994:102) noted cypress was formed into garlands by the "gentiler sort" in the later seventeenth century and rosemary and bay was used by "the Commons" in both funerals and weddings as these survived for a long time, which helped to convey the meaning of solemnity for a longer period than other plants (Drury 1994:102; also see Gittings 1988:110).

There are few references to flowers being specifically used to adorn coffins at this time. Drury (1994:102) discussed historical examples where the madonna lilly (Lilium candidum) was thrown into graves on top of coffins in the hope that it would advert evil. Stone (1858:274) referred to an instance where daisy and "butter'd-flowers" (e.g., buttercups) and rosemary were thrown on the grave of a female, although the age of the individual is not known. Gittings (1988:111) suggested that the use of flowers in both marriages and funerals may point to the continuing cycle of human life where the death of one individual was compensated for by the procreation of future generations. Stone (1858:271) noted that flowers could be placed on the bier of the dead and discussed one report of snowdrops being placed on the bier of a youth or maiden as well as roses, which she associated with providing comfort for the memory of a good man's actions or benevolence (Stone 1858:256). Similarly, there has been little archaeological evidence reported to date for tied bouquets of botanical remains having been found placed on coffins. The examples of bouquets described in this study are significant in illustrating this was a method of botanical commemoration used during the late nineteenth and early twentieth centuries.

The use of bouquets likely developed as part of a growing trend for the outward display of floral remains during the funeral alongside wreath use (see below) but has 
been little documented. Whether this development was predominantly linked to burials from the later nineteenth century needs substantiating in future studies. That these examples were found on burials made in suburban churchyards rather than in densely filled urban burial grounds is likely linked to their survival; botanical remains are unlikely to survive where coffins are directly stacked upon each other, as predominantly found in the mid-nineteenth-century burials from Bethnal Green. The bouquet examples were found in brick-lined graves which prevented direct contact with overlying grave fill, aiding their preservation but making comparisons of the frequency of use between sites with different grave construction difficult. While challenging to interpret, the archaeological evidence is important in expanding current understanding of the variation in the forms of botanical tributes that were used in nineteenth- and early twentieth-century funerary practices.

\section{Wreaths placed on the coffin}

Historical sources do refer to the use of wreaths placed on coffins; May (2000:91) suggested that early in the Victorian period placing wreaths of flowers on the coffin was largely confined to the funerals of girls and young maidens although there is likely mixing here with the use of maiden's garlands which were traditionally made with flowers and strips of paper and hung from a wire bell-shaped wire frame. These were frequently associated with young girls or women and were used to decorate the funerals of young "Maydens" (Drury 1994:103) and Morris (2011) has described these forms in detail. Gittings (1999) noted these garlands could be carried on the coffin during the procession. Drury's (1994:103) historical review referred to funerary garlands made of flowers and leafy branches, including willow, yew, and rosemary, which were carried at funerals or laid on the biers of lovers who had died before their wedding day, or placed on those who had suffered unhappiness. Llewellynn (1860) noted the practice of adorning brides with flowers such as orange blossoms was linked with the thought of flowers as emblems of purity, and this had been adopted for adorning the corpse and coffin and grave of virgins but the custom may have varied regionally. May (2000) reported that evergreens and white flowers, such as roses or lilies were acceptable for such garlands but bright colors were frowned upon. Such botanical tributes formed a visible part of the funeral being carried or placed on the coffin during its procession to the place of burial but these garlands appear to be distinct from funeral wreaths as they were not intended to be kept on the coffin once interred. Maiden's garlands were more often placed inside the church or hung up under a church arch to commemorate the dead (Gittings 1999; Morris 2011) although Stone (1858:255) reports an example of garlands of white roses hung over the grave when a person died young. In contrast, the wreaths and bouquets found at St. Mark's Church, Surbiton, and St. John the Baptist Church, Egham, remained a tribute to the deceased that was kept with the coffin and interred in the grave.

Archaeological evidence for the survival of wreaths has been documented previously; two wire wreath frames were found on the coffin of an adult female from St. Martin's-in-the-Bull Ring Church in Birmingham dating to 1904 (Ciaraldi 2006), which overlaps well with the dates of use for the examples documented from St. Mark's Church, Surbiton. Wreaths were found on burials from St. Bartholomew's Church in Penn, Wolverhampton including five wreath frames found on the coffin of a 
63-year-old female who died in 1897 discussed by Cherryson et al. (2012:79), and an iron ring with foliage was found on a burial dating from 1890 at St. Philip's Cathedral in Birmingham (Cherryson et al. 2012). Mahoney-Swales et al. (2011) describes leaves of laurel and ash possibly from a wreath, found in a grave excavated from St. Paul's Church, Sheffield, with burials at the site predominantly those of wealthy families from 1743 into the 1850s (Mahoney-Swales et al. 2011). At St. Luke's Church, London, Boston and Boyle (2005) described an arrangement of flowers found surviving on top of a coffin of an unnamed young female who died in 1830 and Boyle and Keevill (1998) highlighted floral tributes surviving as wreaths recovered from burials interred at St. Nicholas in Sevenoaks, Kent. Two metal wreath frames embellished with metal leaves representing oak, horse chestnut, ivy and possibly beech, were also found in the disturbed vaults of an Egyptian-style chapel in the Sheffield General Non-Conformist Cemetery in use between 1836 and 1978 (Harvey 2012) in a similar fashion to one example of a metal wreath with detailed leaves found from St. Mark's Church, Surbiton.

The expanding use of wreaths in funeral commemoration during the nineteenth century may be linked to a growing cultural interest in botanics and sociocultural practices that ascribed significance to certain flowers, including the development of the Language of Flowers which through numerous publications gave the meanings of different plants and their significance in daily life, whether given as gifts, or by suitors, or in illness (see Goody 1993:263; Seaton 1995). However, Boston and Boyle (2005) have argued that the depiction of botanical remains was already a widely accepted part of the embellishment of coffins during the eighteenth and nineteenth centuries as images of flowers and foliage designs were incorporated on coffin plates and lid motifs. Well-preserved examples were abundant on adult and child coffins at Bethnal Green and included draped urns holding stylized roses, daises, daffodils and sunflowers (Fig. 5). Additionally, an ideological shift towards a desire for idyllic landscape garden cemeteries to replace overcrowded urban burying grounds, most likely interlinked with concerns over epidemic disease mortality due to cholera outbreaks (Stevens Curl 2000:23; Rugg 1998), may also have coincided with the move towards greater integration of botanical remains into funerary traditions. The direct incorporation of wreaths and bouquets as a visible part of the funeral may also have been a logical step moving towards the outward display of mourning and commemoration, shifting away from more private means of botanical commemoration. Litten (1991:170) has suggested that the growing use of private cemeteries required processions from the church to the burying ground which were likely to have influenced the adoption of more visible displays of commemoration including the use of floral tributes in the late $1860 \mathrm{~s}$. By the 1880s it had become fashionable to send wreaths to cover the coffin (Goody 1993:303) and growing popularity in the provision of wreaths is evident among trade advertisements, such as that for Osman and Co. from London in 1888 which specified the ready supply of wreaths and wires in a variety of shapes (May 2000:10) some of which match the variety of wreath designs found at St. Mark's Church, Surbiton, and are likely indicative of families and acquaintances who could afford commemorative embellishments. Contemporary newspaper adverts also demonstrate the growing trend for the supply of funeral flowers; advertising in the Illustrated London News on October 2, 1880 for example, William Hooper offered to supply "Pretty flowers, bridal bouquets, bridesmaid's bouquets, baskets of flowers, loose cut flowers, funeral 
wreaths" (Hooper 1880). In the Midlands, William Fisher (1880) announced on August 19, 1880 in the Burton Chronicle he had commenced business as a florist and seedsman and could provide "wedding-bouquets, funeral wreathes, dress and coat flowers to order." Hardings (1880), advertising as a Royal Florist in the Morning Post on November 20, 1880 could supply "Funeral Wreaths and Crosses of beautiful choice, white natural flowers" from New Bond Street, London. Additional botanical funerary developments included the use of immortelles comprising small porcelain flowers placed under glass domes and left at the graveside from the 1890s (Litten 1991:170); a surviving example was found on the floor of the Sheffield General Cemetery chapel during archaeological works (Harvey 2012).

Historians of Victorian funerary traditions have emphasized the move away from ostentatious funerary displays that involved large processions and a wealth of decorative accessories from the mid-nineteenth century, and the subsequent adoption of more simple and solemn funerary traditions (Jalland 1996:222; Stevens Curl 2000). However, the adoption of floral tributes provided a different visual avenue of commemoration and grief and by extending the outward display of funeral itself, these tributes became an ostentatious practice. Indications of apparent extravagance may be suggested by the number of wreaths included on several coffins from St. Mark's Church, Surbiton, although interpretations are made inherently complex by unknown factors such as the size of the surviving family and friends, and/or working colleagues or acquaintances all of whom may have donated wreaths for a burial. Reports of the extensive use of botanical remains at funerals have been recorded; in a one example a grave was fully lined with ivy and moss so that mourners saw " "nothing but the beautiful mass of white flowers among the green' as the coffin was lowered" (Jalland 1996:223), and in her
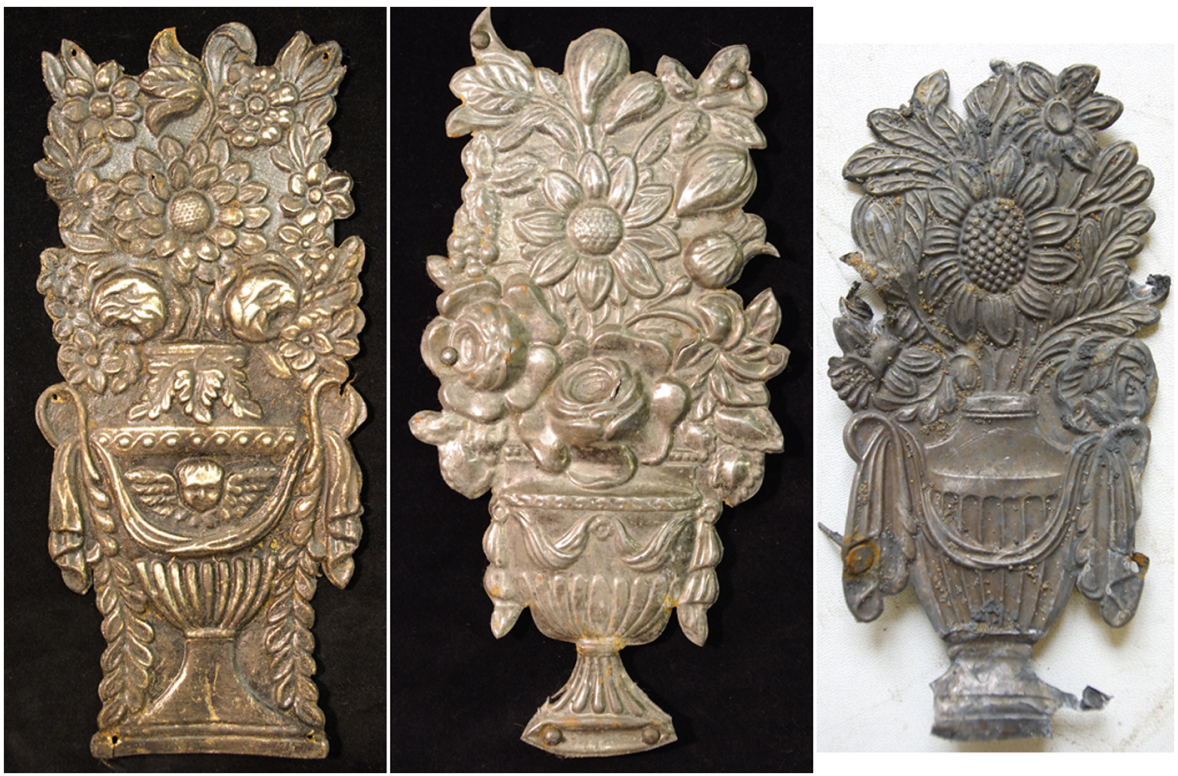

Fig. 5 Examples of metal coffin lid decorations of draped urns holding a range of flowers representing daffodils, roses and rose buds, possible daisies, and sunflowers. Examples from adult coffins from St. John's School, Bethnal Green, London 
review of working-class funerary and mourning practices Strange (2002) reported on individual perceptions of grand funerals witnessed by individuals from the working classes where one recollection referred to a lavish funeral drawing crowds of spectators that reportedly gasped at the numbers of wreaths, although it was noted that extravagance did not necessarily equate to respectability.

The extent of funerary extravagance of botanical commemoration was also questioned in newspapers; in Liverpool, for example, a comment published Huddersfield Daily Examiner on February 14, 1891, rallied for a movement against such a "costly fashion" asking "Why get rid of mutes, plumes, hatbands, scarves... if we are to be ruined by the growing rivalry of mourners, each determined to lay on the coffin of the deceased friend a bigger and better wreath than his fellow-mourners can afford?" (Anonymous 1891:1). Extravagant expenditure was similarly questioned on November 10, 1893, in the South Wales Daily News as to whether or not it could be better devoted to charitable purposes instead as "to cover the coffin of a dead friend with flowers is admitted to be a beautiful custom, but the funeral wreath has long become little more than a fashion, involving a tax often grudgingly paid" (Anonymous 1893:3). Mrs Elizabeth Sherwood wrote in 1887 that the custom of decorating a coffin with flowers has been overdone but that "a few flowers placed in the dead hand, perhaps a simple wreath, but not those unmeaning memorials which have become to real mourners such sad perversities of good taste, such misuse of flowers" (Sherwood 1887). Walvin (1982: 365 citing Roberts 1971) cites an example from the late nineteenth century where a community whip-round was needed to help pay for a funeral comprising "a sheet donated to form the shroud, money collected for flowers and a box given for a baby's coffin." The latter is an interesting example demonstrating that notions of funerary respectability had developed by this time to include the use of floral remains.

\section{Childhood commemoration}

There is a clear bias in the number of adults found with plant-based tributes at the three sites surveyed here compared to children with botanical remains, however, this is influenced by the relatively small number of child burials discovered in the areas of archaeological works at both St. Mark's Church, Surbiton, and St. John the Baptist Church, Egham. Variation in the placement of children's burials in burial grounds will clearly affect the recovery of archaeological evidence of funerary practices between different demographic groups complicating between site comparisons of the frequency of tributes. Despite this, the archaeological evidence does show that wire wreath frames were found on child coffins at St. Mark's Church, Surbiton, and demonstrates that the funerals of some children were commemorated in a similar manner to several adults at this site and moreover, this pattern was not limited to family groups, which may have a tendency to follow similar burial practices. The results show that some children had more than multiple wreaths placed over the coffins which indicates that a relative elaborate expression of commemoration during the funeral was not restricted to adults only. The use of wreaths as well as floral remains placed inside the coffin shows that child deaths were recognized and commemorated and not overlooked despite periods of high levels of child mortality. That not all children were commemorated in the same manner raises questions that need future exploration in terms of significance, but these must be carefully balanced by understanding the limitations caused by preservation. It 
is clear that the archaeological evidence of botanical commemorations is important in allowing the development of interpretations of social responses to death and shows that interpretations of the manner of tributes to the deceased may not be adequately gauged by above-ground monuments or historical evidence alone. The wide spread of dates of burials found with botanical remains highlights there is potential for burials from elsewhere covering a similar date range to have botanical inclusions and as more sites are archaeologically investigated, further evidence will be uncovered that will help shape existing research questions and develop the observations made here.

\section{Local variation in use of botanical tributes}

Regional variations and local developments in the funerary trade are important factors that can impact the type of material culture found in burial archaeology (e.g., MahoneySwales et al. 2011:228). As evidence from the current study is drawn from several close areas between Surrey and London, these sites can provide insights into the potential extent of local rather than regional variation. However, variation was clear in the sample through the exceptional number of wreath frames found with burials interred at St. Mark's Church, Surbiton, which are not matched by archaeological evidence from other sites in the UK to date. This high frequency of wreaths found on coffins from St. Mark's Church, Surbiton, may be linked to the long period of use of the ground for burials and the continuation of burials into the early twentieth century as burials with wreaths from this site predominantly dated between 1873 and 1897, which aligns with historical evidence indicating a growing tendency for the inclusion of wreaths in funerals towards the end of the nineteenth century. However, the suburban burial ground at St. Mark's Church, Surbiton, was also purpose-built and the burial space was extremely well-managed with consistent and orderly arranged brick-built graves in the two areas of the churchyard explored archaeologically, and these factors are likely to have significantly contributed to the survival of the botanical remains at this site. Some of the burials from St. John's Church, Egham, also continued into the later nineteenth century and the construction of brick-built graves for some of the burials at St. John's Church, Egham, also led to good levels of coffin preservation and the survival of bouquet remains. However, the predominant use of earth-cut graves at St. John's Church, Egham, which were frequently truncated, may have disproportionately affected the survival of botanical remains, which complicates approaches seeking to compare the frequency of tributes between the sites. There is likely to be a bias in surviving remains found in optimum conditions and especially brick-built graves, which may affect interpretations of the temporal frequency of use of these tributes.

Some burials from St. Mark's Church, Surbiton, demonstrated notable elaboration of decorative metal coffin embellishments (see Ives 2013) and while the inclusion of wreaths demonstrates a relative simplification of the funeral process, at this site echoes of elaboration are clear. The large number of wreaths from St. Mark's Church, Surbiton, reflect the funerary traditions developing at this time to include the outward display of wreaths, these examples also indicate local variation in the degree of elaboration for commemorating burials. It is likely this was influenced by the growing availability of wreaths advertised and available from florists at this time and local undertakers may have become involved in the provision of wreaths as part of the funeral, Parsons (2018:26) for example, reported wreaths and immortelles placed in the 
window of Beckett and Son's office in 1912 as advertising for their funeral services. Some documentary evidence does indicate local and regional variation may have existed favouring the use of different plants for ceremonies; Stone (1858:273), for example, noted that rosemary was commonly used in weddings but was in "greater request at funerals in Staffordshire, Cumberland, and other parts of England" and future studies may be able to reveal further variation between types of tributes and plants used in the funeral. While interpretations of funerary extravagance can be suggested based on the surviving multiple wire wreath frames from St. Mark's Church, Surbiton, the recovery of a hay cross commemorating a burial from St. John the Baptist Church, Egham, is also a significant find. This demonstrates that traditional funerary iconography indicated in the mid- to late nineteenth century in metal lid decorations in the form of the cross and similarly represented in wire wreaths forms was also represented in organic forms. This form of botanical tribute may have been more used more widely during the nineteenth century, but evidence of usage can be biased by the odds of survival, which also needs accounting for when comparing and interpreting and understanding aspects of funerary traditions and past burial cultures.

\section{Conclusions}

This paper aimed to develop current understanding of how botanical tributes were used in post-medieval funeral practices through a comparative analysis of the types, frequency, and demographic patterning in evidence of botanical tributes from three archaeological investigations. The results demonstrate that three different forms of tribute, represented by flowers placed inside the coffin as well as bouquets and wreaths placed on top of the coffin, were in use from the nineteenth century and this study shows that these tributes were used for adults and children and males and females. As many sites of late nineteenth- and early twentieth-century date are archaeologically investigated with or are contingent upon exhumation, which comprises the removal of burials without any contextual or archaeological recording, drawing attention to the range of botanical inclusions found across several recent archaeological investigations may raise awareness of the survival of such funeral practices and illustrate the variety of botanical inclusions that can survive among post-medieval burials. In this study, floral tributes placed inside the coffins were evident from the mid-nineteenth century, which aligns with evidence from other sites across England, but notably the flowers presented here expand on those previously known to have been used during funerals. There also appears to be a trend for the increased use of wreaths and bouquets from the later nineteenth and early twentieth centuries from the sites studied, which broadly supports documentary reports of wreath use in funerals and the growing market for wreath supply. However, there is evidence from other sites which indicates wreaths may have been in use earlier in the nineteenth century and the rare survival of a plant-based form of wreath in the shape of a cross reported here clearly demonstrates that our evidence is contingent upon survival. Taphonomic differences existing between sites and between differing burial practices (earth-cut vs brick-built graves) can affect the survival of botanical tributes and influence interpretations drawn from an incomplete record. Local variation and socioeconomic status are also likely to have influenced the frequency and types of use of such tributes and such patterns will only become clear through 
comparative studies. The different expressions of use clearly demonstrate that botanical tributes formed an important part of the post-medieval funeral process and represented personal expressions of grief or mourning and/or commemoration through bouquets and flowers in the coffin, as well as a more widely adopted funerary practice of wreath use.

Open Access This article is licensed under a Creative Commons Attribution 4.0 International License, which permits use, sharing, adaptation, distribution and reproduction in any medium or format, as long as you give appropriate credit to the original author(s) and the source, provide a link to the Creative Commons licence, and indicate if changes were made. The images or other third party material in this article are included in the article's Creative Commons licence, unless indicated otherwise in a credit line to the material. If material is not included in the article's Creative Commons licence and your intended use is not permitted by statutory regulation or exceeds the permitted use, you will need to obtain permission directly from the copyright holder. To view a copy of this licence, visit http://creativecommons.org/licenses/by/4.0/.

\section{References}

Anonymous. (1891). Funeral Wreaths. Huddersfield Daily Examiner, p. 3. <https://search.findmypast.co.uk/ bna/viewarticle?id=b1\%2f0000901\%2f18910214\%2f241\&stringtohighlight=funeral\%20wreaths $>$, Accessed Mar 2020.

Anonymous. (1893). Funeral Wreaths. South Wales Daily News, p. 3. <https://search.findmypast.co.uk/bna/ viewarticle?id=bl\%2f0000919\%2f18931110\%2f009\&stringtohighlight=funeral\%20wreaths $>$, Accessed Mar 2020.

Boston, C. and Boyle, A. (2005). Burial practice and material culture. In Boyle, A., Boston, C., and Witkin, A. (eds.), The Archaeological Experience at St Luke's Church, Old Street, Islington. Oxford Archaeology Report, Oxford, pp. 82-127. <https://library.oxfordarchaeology.com/167/7/OLR00.pdfA.pdf>, Accessed Feb 2020.

Boyle, A. and Keevill, G. (1998). To the praise of the dead and anatomie: the analysis of post-medieval burials at St. Nicholas, Sevenoaks, Kent. In Cox, M. (ed.), Grave Concerns. Death and Burial in England 17001850. Council for British Archaeology, York, pp. 85-96.

Capon, L. and Ives, R. (2015). St. John the Baptist Church, High Street, Egham, Surrey: A Post-Excavation Assessment Report. AOC Archaeology Group, London.

Cherryson, A., Crossland, Z., and Tarlow, S. (2012). A Fine and Private Place. The Archaeology of Death and Burial in Post-Medieval Britain and Ireland. Leicester Archaeology, Leicester.

Ciaraldi, M. (2006). Plant offerings. In Brickley, M., Buteux, S., Adams, J., and Cherrington, R. (eds.), St. Martin's Uncovered. Investigations in the Churchyard of St Martin's-in-the-Bull Ring, Birmingham, 2001. Oxbow Books, Oxford, pp. 184-186.

Connell, B. and Miles, A. (2010). The City Bunhill Burial Ground, Golden Lane, London. Excavations at South Islington Schools, 2006. Museum of London Archaeology, London.

Cox, M. (1998). Eschatology, burial practice and continuity: a retrospection from Christ Church, Spitalfields. In Cox, M., Grave Concerns. Death and Burial in England 1700-1850. Council for British Archaeology, York, pp. 112-26.

Cunnington, P. and Lucas, C. (1972). Costume for Births, Marriages and Deaths. Adam and Charles Black, London.

Davis, A. and Miles, A. (2012). Plant remains. In Miles, A. and Connell, B. (eds.), New Bunhill Fields Burial Ground, Southwark. Excavations at Globe Academy, 2008. Museum of London Archaeology, London, pp. 56-58.

Drury, S. (1994). Funeral plants and flowers in England: some examples. Folklore 105: 101-103.

Fisher, W. (1880). Advertisement. Burton Chronicle, Burton, England, p. $1<$ https://search.findmypast.co.uk/ bna/viewarticle?id=b1\%2f0002871\%2f18800819\%2f012\&stringtohighlight=funeral\%20wreaths $>$, Accessed Mar 2020.

Fletcher, A. (2010). Growing Up in England: The Experience of Childhood 1600-1914. Yale University Press, New Haven, CT. 
Gavin, H. (1848). Sanitary Ramblings being Sketches and Illustrations of Bethnal Green a Type of the Condition of the Metropolis and Other Large Towns. J. Churchill, London.

Giorgi, J. (2011). Plant remains. In Emery, P. and Wooldridge, K. (eds.), St. Pancras Burial Ground. Excavations for St Pancras International, the London Terminus of High Speed 1, 2002-2003. Museum of London Archaeology, London, pp. 188-189.

Gittings, C. (1988). Death, Burial and the Individual in Early Modern England. Routledge, London.

Gittings, C. (1999). Sacred and secular: 1558-1660. In Jupp, P. and Gittings, C. (eds.), Death in England: An Illustrated History. Manchester University Press, Manchester, pp. 147-173.

Goody, J. (1993). The Culture of Flowers. Cambridge University Press, Cambridge.

Hardings, (no initial). (1880). Advertisement for funeral wreaths. Morning Post, p. 1. <https://search. findmypast.co.uk/bna/viewarticle?id=bl\%2f0000174\%2f18801120\%2f002\&stringtohighlight=funeral $\%$ 20wreaths>, Accessed Mar 2020.

Harvey, L. (2012). Finds report. In McIntyre, L. and Harvey, L. Non-Conformist Chapel Crypt Survey, General Cemetery, Sheffield Report No. GCNC01. Department of Archaeology, University of Sheffield, Sheffield, UK.

Hooper, W. (1880). Advertisement for pretty flowers. Illustrated London News, p. 335. <https://search. findmypast.co.uk/bna/viewarticle?id=bl\%2f0001578\%2f18801002\%2f048\&stringtohighlight=funeral $\%$ 20wreaths>, Accessed Mar 2020.

Houlbrooke, R. (1998). Death, Religion and the Family in England, 1480-1750. Oxford University Press, Oxford.

Ives, R. (2013). Life and death in suburbia: archaeological work at St. Mark's Church, Surbiton. London Archaeologist 13 (8): 205-210.

Ives, R. (2015). Insights into health, life and death in Victorian London's east end. London Archaeologist 14 (6): 150-154.

Ives, R. and Hogg, I. (2012). St. John's School, Peel Grove, Bethnal Green, London Borough of Tower Hamlets: A Post-Excavation Assessment Report. AOC Archaeology Group, London.

Jalland, P. (1996). Death in the Victorian Family. Oxford University Press, Oxford.

Jarvis, H. W. (1960). Beauty for Ashes. Surbiton Parish Church. John Roberts, Surbiton.

Laqueur, T. (1983). Bodies, death, and pauper funerals. Representations 1:109-131.

Litten, J. (1991). The English Way of Death. The Common Funeral Since 1450. Robert Hale, London.

Llewellynn, J. (1860). On funeral garlands. The Relinquary: Quarterly Archaeological Journal and Review 1: $5-11$.

Mahoney-Swales, D., O’Neill, R., and Willmott, H. (2011). The hidden material culture of death: coffins and grave goods in late $18^{\text {th }}$ and early $19^{\text {th }}$ century Sheffield. In King, C. and Sayer, D. (eds), The Archaeology of Post-Medieval Religion. Boydell, Woodbridge, pp. 215-231.

May, T. (2000). The Victorian Undertaker. Shire, Princess Risborough.

Morris, R. (2011). Maiden's garlands: a funeral custom of post-Reformation England. In King, C. and Sayer, D. (eds.), The Archaeology of Post-Medieval Religion. Boydell, Woodbridge, pp. 271-282.

Mytum, H. (1989). Public health and private sentiment: the development of cemetery architecture and funerary monuments from eighteenth century onwards. World Archaeology 21: 283-297.

Mytum, H. (2018). United in death? a comparative introduction to historic mortuary culture. In Mytum, H. and Burgess, L. (eds.), Death Across Oceans: Archaeology of Coffins and Vaults in Britain, American, and Australia. Smithsonian Institution Scholarly Press, Washington, DC, pp. 1-19.

Parsons, B. (2018). The Evolution of the British Funeral Industry in the $20^{\text {th }}$ Century: From Undertaker to Funeral Director. Emerald, Bingley.

Pitt, N., Casey, M., Lowe, A., and Stocks, R. (2017). The old Sydney burial ground: the 2008 archaeological investigations. Australasian Historical Archaeology 35: 3-23.

Powers, N. (2015). A Draft Agenda for the Archaeological Study of Historic Burials in Greater London. Allen Archaeology Ltd., Lincoln.

Puckle, B. (2008 [1926]). Funeral Customs: Their Origin and Development. Forgotten Books, London.

Renshaw, L. and Powers, N. (2016). The archaeology of post-medieval death and burial. Post-Medieval Archaeology 50 (1): 159-177.

Robert Roberts, R. (1971). The Classic Slum. Penguin, London.

Robertson, J. (2012). Botanical remains. In Ives, R. and Hogg, I. St. John's School, Peel Grove, Bethnal Green, London Borough of Tower Hamlets: A Post-Excavation Assessment Report. AOC Archaeology Group, London.

Rugg, J. (1998). A new burial form and its meanings: cemetery establishment in the first half of the $19^{\text {th }}$ century. In Cox, M. (ed.), Grave Concerns. Death and Burial in England 1700-1850. Council for British Archaeology, York, pp. 44-54. 
Russell, J. (1853). Memoirs, Journal and Correspondence of Thomas Moore 1792-1878, VI. Longman, Brown, Green, and Longmans, London, pp. 18-22.

Seaton, B. (1995). The Language of Flowers: A History. University of Virginia Press, Charlottesville.

Sherwood, E. (1887). Manners and Social Usages. Harper and Brothers, New York.

Stevens Curl, J. (2000). The Victorian Celebration of Death. Sutton, Stroud.

Stone, E. (1858). God's Acre, or Historical Notices Relating to Churchyards. John W. Parker and Son, London.

Strange, J. M. (2002). "She cried a very little": death, grief, and mourning in working-class culture, c. 18801914. Social History 27 (2): 143-161.

Tarlow, S. (2015). Introduction: death and burial in post-medieval Europe. In Tarlow, S. (ed.). The Archaeology of Death in Post-Medieval Europe. De Gruyter, Warsaw, pp. 1-18.

Walford, E. (1894). Greater London: A Narrative of its History, its People, and its Places, Volume 2. Advanced Media, London.

Walvin, J. (1982). Dust to dust: celebrations of death in Victorian England. Historical Reflections 9 (3): 353 371.

Publisher's Note Springer Nature remains neutral with regard to jurisdictional claims in published maps and institutional affiliations. 